DOI: https://doi.org/10.34069/AI/2022.49.01.14

How to Cite:

Sandyha, L., Oliinyk, I., Petrovsky, M., Shevchenko, L., \& Sviatiuk, Y. (2022). Selfie neologisms in social networks. Amazonia Investiga, 11(49), 126-135. https://doi.org/10.34069/AI/2022.49.01.14

\title{
Selfie neologisms in social networks
}

\section{Селфі неологізми у соціальних мережах}

Received: December 5, $2021 \quad$ Accepted: January 15, 2022

\author{
Written by: \\ Liliia Sandyha ${ }^{53}$ \\ Web of Science Researcher ID: ABG-3106-2021 \\ https://publons.com/researcher/4103917/liliia-sandyha/ \\ https://orcid.org/0000-0002-3124-664X \\ Iryna Oliinyk ${ }^{54}$ \\ Web of Science Researcher ID: N-4098-2019 \\ https://publons.com/researcher/2908777/ iryna-oliinyk/ \\ https://orcid.org/0000-0001-5933-6818 \\ Mykola Petrovsky ${ }^{55}$ \\ Web of Science Researcher ID: AAV-7529-2021 \\ https://publons.com/researcher/4614275/ mykola-petrovsky / \\ https://orcid.org/0000-0003-3267-7123 \\ Liudmyla Shevchenko ${ }^{56}$ \\ Web of Science Researcher ID: N-4497-2018 \\ https://publons.com/researcher/1527459/liudmyla-shevchenko/ \\ https://orcid.org/0000-0002-4543-3876 \\ Yulia Sviatiuk ${ }^{57}$ \\ Web of Science Researcher ID: E-4978-2016 \\ https://publons.com/researcher/2288318/yulia-sviatiuk/ \\ https://orcid.org/0000-0001-8343-1890
}

\begin{abstract}
The paper deals with modern trends in word formation connected with the development of virtual communication, social networks distribution and the possibility to be present in cyberspace on a permanent basis. The research concentrates on social media interaction as the main source of neologisms that reflect and describe digital portraits Internet users make and post on the web. Preconditions for newly coined words to continue their existence and become common are considered. Digitalization provides a large spectrum of opportunities for neologisms to be noticed by a wider audience and creates a demand for new coinages. At the same time, a new word should be similar to those existing in a given language in order to arouse interest of potential users. For this reason, the article considers different mechanisms of neological word formation that proved to be efficient. The
\end{abstract}

\section{Анотація}

У статті розглядаються сучасні тенденції словотворення, пов'язані 3 розвитком віртуальної комунікації, поширенням соціальних мереж та можливістю постійної присутності в кіберпросторі. Дослідження зосереджується на спілкуванні у соціальних мережах як основного джерела неологізмів, які відображають i описують цифрові портрети, які користувачі Інтернету створюють i публікують у мережі. Розглядаються передумови для того, щоб нові слова продовжували своє існування та ставали загальноприйнятими. Діджиталізація надає широкий спектр можливостей для неологізмів бути поміченими ширшою аудиторією та створює попит на нові утворення. При цьому неологізм має бути схожим на лексеми, які існують у даній мові, щоб викликати інтерес у потенційних

\footnotetext{
${ }^{53}$ Ph.D. Phil, Taras Shevchenko National University of Kyiv, Ukraine.

${ }^{54}$ Ph.D. Phil, Taras Shevchenko National University of Kyiv, Ukraine.

${ }^{55} \mathrm{Ph}$.D. Phil, Taras Shevchenko National University of Kyiv, Ukraine.

${ }^{56} \mathrm{Ph}$.D. Phil, Taras Shevchenko National University of Kyiv, Ukraine.

${ }^{57}$ Ph.D. Phil, Taras Shevchenko National University of Kyiv, Ukraine
} 


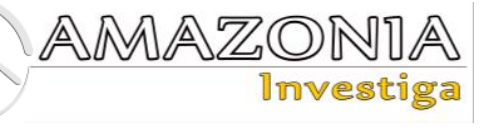

methods used allow to assess the derivational potential of new coinages, define the most productive word building techniques, adequately interpret the words' meaning and classify the neologisms under consideration into groups. The results obtained show relevance of digital portrait-based coinage in modern English and demonstrate prospects for further research in the field of digital communication neology.

Key words: blending, digitization of communication, neologism, nonce-formation, selfie.

\section{Introduction}

It is definitely hard to exaggerate the role of a person's digital presence in the $21^{\text {st }}$ century. In today's world people's image in social networking sites seems to be sometimes more important than their offline appearance due to the digitization of communication which gives people a possibility to connect with spatially distant people within seconds. Body-centrism and narcissism promoted to such a great extent by numerous celebrities in social networks is affecting teenagers and young adults and seems to have started and in some cases to have won the fight with a permanent elaboration of a person's inner world and one's virtues. Mass obsession with one's social network profiles and self-made portraits made the buzzword 'selfie' the Oxford Dictionaries Word of the Year 2013 (Ahmed, 2017). Further on it became the parent-word for other numerous neologisms of self-taken pictures which can now be flatly categorized. The authors' primary research focus is on the neologisms which name various types of selfies shared in online communication and the adjacent phenomena.

It's a well-known fact that neologisms have been the focus of research of numerous linguists, such as J. Algeo, D. Crystal, R. Fischer, A. Lehrer, P. Hohenhaus, A. Mcmahon, K. Maxwell, A. Rey, P. Stekauer, M. Mostovyi, and many others all of whom have proposed different approaches to defining the term. Some linguists focused on specific spheres in which neologisms are born, for instance, K. Karpova (2019) studied culinary neologisms in the English language, O. Horbach and O. Hryniuk (2018) analyzed German compound neologisms in marketing. In this study we consider the variety of terminological approaches to defining користувачів. У дослідженні розглядаються продуктивні механізми неологічного словотворення. Використані методи дозволяють оцінити дериваційний потенціал неологізмів, визначити найпродуктивніші прийоми словотворення, якісно інтерпретувати значення слів та класифікувати розглянуті неологізми за групами. Отримані результати свідчать про актуальність неологізмів, які називають нові види цифрових портретів у сучасній англійській мові та демонструють перспективи подальших досліджень у сфері онлайн неології.

Ключові слова: телескопія, діджиталізація, неологізм, оказіоналізм, селфі.

'neologisms' as opposed to 'nonce-formations' and provide our own definition of both phenomena.

The research also considers productive wordforming mechanisms of new types of selfies and digital networking phenomena, namely affixation, blending, compounding, repurposing and the combination of two word-forming mechanisms.

\section{Theoretical Framework}

First of all, let us study different definitions of the term 'neologism' and taking them all into consideration, propose our own definition. It is difficult to disagree with a Ukrainian researcher M. Mostovyi (1998) who states that linguists and lexicographers have not so far and will probably never reach terminological unanimity in defining 'neologisms' as there are no clear criteria to do so. What is more, it is necessary to consider the distinction between neologisms and nonceformations (often referred to as occasionalisms by many linguists).

A. Rey (1995) defines a neologism as a "unit of the lexicon, a word, a word element or a phrase whose meaning, or whose signifier - signified relationship, presupposing an effective function in a specific model of communication, was not previously materialized as a linguistic form in the immediately preceding tag of the lexicon of the language. According to the model of the lexicon chosen, the neologism will be perceived as belonging to the language in general or only to one of its special usages; or as belonging to a subject - specific usage which may be specialized or general". Interestingly, A. Rey 
(1995) mentions that in the $3^{\text {rd }}$ edition of Webster's Dictionary a neologism is defined as "a meaningless word coined by a psychotic".

P. Hohenhaus (2005) notes that nonceformations and neologisms are frequently used as synonymous terms, however, the linguist disagrees with such an approach. P. Hohenhaus states that the former are new coinages in the absolute sense, whose existence is typically limited to a single occasion, therefore, nonceformations are somewhat in between actual words and possible words. On the other hand, neologisms are not new in the absolute sense, as they are the existing vocabulary, their novelty is diachronical. Thus, when a nonce-word starts being used by other speakers, it acquires the status of a neologism, which the linguist calls a transitional phenomenon as its status of a nonceformation has been lost, however, it has not been fully institutionalized yet.

R. Fischer (1998) proposes two approaches to defining nonce-formations. On the one hand, the linguist states that nonce-formations are spontaneous coinages which are rarely used. On the other hand, in accordance with Keller's theory of language change nonce-formations may be treated as intentional linguistic actions. When a certain number of speakers start using a formation with similar intentions, institutionalization starts with a nonce-formation being transformed into a neologism (Fischer, 1998).

D. Crystal (2008) claims that spontaneity and purposefulness are both possible in the process of nonce-word formation. The linguist defines a nonce-word as 'a linguistic form which a speaker consciously invents or accidentally uses on a single occasion [...] Nonce formations have occasionally come to be adopted by the community - in which case they cease, by definition, to be 'nonce' (forms used 'for the (n)once'), and become neologisms'.

We support both approaches to defining the term, i.e. the spontaneous and the intentional ones, as we consider that the intentional character of forming certain neologisms may be explained by an author's desire to create a special expressive word or a collocation to produce a particular stylistic effect.

R. Fischer (1998) states that a neologism is a word whose status of a nonce-formation has been lost, however, it is still considered to be new by most members of a given speech community. The linguist adds that familiarity, availability and learnability are crucial for the survival of neologisms, however, it is frequency and coverage that are the most important factors for a neologism's inclusion in the dictionary. R. Fischer also stipulates that most dictionaries label their headwords in accordance with their frequency as follows: rare (one citation), infrequent (from two to ten citations), common (from eleven to 100 citations), frequent (more than 100 citations). On the other hand, P. Stekauer (2010) claims that 'frequency of usage' is an unreliable and vague term in this respect which we fully agree with.

A Ukrainian researcher of neology K. Nykytchenko (2015) defines occasionalisms as "words or meanings of words, invented to meet the needs of a particular occasion in order to catch the reader's attention, shock or provoke, create hidden meanings (semantic condensation) and express the author's evaluation".

According to the recent statistics provided by the Global Language Monitor, approximately 5,400 new words appear annually, however, it is only around 1,000 of them that find their way to printed press (Bodle, 2016).

A. McMahon (1994) notes all neologisms have to contend with a conservative mindset rejecting their existence and the linguist claims there are two opportunities for neologisms of any kind to live on in a certain culture. Firstly, the chances for survival are high should they be introduced by an outstanding person or published by a reputable source (also Bodle, 2016; Evans, 2012). Thus, the 1960s neologism grok which was invented by an American author Robert Heinlein in his novel Stranger in a Strange Land (Evans, 2012) managed to enter the mainstream later on and is now defined in the Oxford Advanced Learner's Dictionary as '(US English, slang) to understand something completely using your feelings rather than considering the facts' (OALD). Similarly, $M c J O b$, coined by a sociologist Amitai Etzioni in the Washington Post to denote 'a low-paying job that requires little skill and provides little opportunity for advancement' (MWD) and popularized by Douglas Coupland in his Generation X: Tales for An Accelerated Culture may serve as another example of a prominentsource newborn (Evans, 2012).

Therefore, we disagree with K. Nykytchenko (2015) who states that 'the creators of neologisms remain unknown' as we believe that in most cases nowadays it is possible to identify the authorship of a certain neologism. 


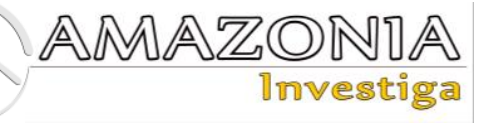

The second reason for acceptance is when a certain society deems the denomination of certain notions and objects to be necessary (McMahon, 1994). Undoubtedly, a vast majority of new words appear when the need to denominate new phenomena and objects arises. Interestingly, there have been instances when the same neologisms were thought up by different people who state they were unaware of each other. One of the examples is 'software', which, according to A. Metcalf (2002) was born twice. The first 'parent' of the computer term is J. W. Tukey, a statistician at Princeton University who used the neologism in the American Mathematical Monthly in 1958. Surprisingly (or on the contrary), the term was created by an electrical engineer from California P. Niquette who claimed to have coined 'software' as a prank in 1953 and to have used it in his numerous lectures and speeches. However, the scientist never believed it would ever be taken seriously. Overall, A. Metcalf states that the lexeme was predestined to be coined those days as there was an urgent need for it to name a new phenomenon.

The authors of this article assume that three reasons are vitally important for a new coinage to continue its existence. Firstly, any neologism is bound to originate in a public cradle, otherwise it does not stand a chance of being introduced to the general society and thus may be treated only as a nonce-formation. Secondly, the demand for a denomination of a new phenomenon must spur its creation. The last but not the least, the authors of this work agree with R. L. Evans (2012) who states that for a neologism to start being commonly used, it must bear resemblance to other words.

D. Minkova and R. Stockwell (2009) also note that rarely are words coined from scratch, in most cases they are based on some pre-existing word or its part. As it has already been mentioned, most humans are conservative by nature and adopting a new lexeme might be a real challenge unless it follows conventional word-formation patterns. Exceptions to the rule may certainly exist, however, it is difficult to find the supporting statistics (Maxwell, 2006)..

As regards neological word formation, most linguists provide 12 main mechanisms of word formation, namely:

1) derivation (e-waste, pre-clashed, previsualize, undertourism, slashie);

2) compounding (selfie-conscious, SelfieFever, serial returner);
3) blending or portmanteaus (selfiecide, gravatar, walkumentary);

4) clipping (celeb, perm, tux);

5) conversion (to friend, genius);

6) abbreviations (LOTFL, FONC, cab);

7) loanwords (tycoon, taboo, flea market);

8) back formation (edit>editor, liaise >liaison, donation $>$ donate)

9) repurposing (gate>Watergate, deflategate, gamergate, nipplegate);

10) eponyms (Alzheimer's, wellington, sandwich);

11) onomatopoeia (bunch, bump, cuckoo);

12) reduplication (flip-flop, picnic, hip hop);

13) error (scramble > scrabble) (Lehrer, 1996; McMahon, 1994; Bodle, 2016).

Moreover, some words undergo a combination of methods, for instance 'yuppie' is a combination of initialism ((y)oung and (up)wardly mobile) and suffixation (-ie).

A. Bodle (2016), however, states it is the portmanteau that is the 'only player in town' in terms of neological formation. A. Lehrer (1996) also notes that 'blending has become a truly productive process in contemporary word formation, not only in English, but in French, German, and other languages'

A. McMahon (1994) in her turn claims it is affixation and compounding which are the most productive techniques in English, whereas conversion, blending, clipping, back formation and acronyming are used less often. K. Ahmad (2000) notes that around 40 per cent of neologisms in Merriam Webster were formed by means of affixation, and approximately 60 per cent underwent compounding.

It should also be noted that classification of neologisms into word-formation mechanisms may pose certain challenges as words can be categorized differently by speakers, moreover, classification can change. A. Lehrer (1996) illustrates it with the word 'workaholic', a blend of 'work' and 'alcoholic'. In the process of resegmentation '-(a)holic' has become a part of other lexemes referring to certain addictions or obsessions (sugarholic, foodoholic, chocoholic, shopaholic) and for some speakers it functions as an independent suffix. Nonetheless, other speakers still treat new obsessions as blends of 'alcoholic' plus other words.

Taking into account the aforementioned approaches to defining neologism, we define the latter as a recently coined or an existing word or a word combination which names a new 
phenomenon or concept but which is still not actively used by most members of a speech community. By contrast, a nonce-formation is either a spontaneous coinage created to meet a one-off communicative need or an intentional author's playful creation coined to impress a reader.

\section{Methodology}

In the course of research 75 neologisms denoting new types of selfies (38 items) and other phenomena connected with communication in social media (37 items) were selected by means of sampling from the following lexicographic sources: About Words - Cambridge Dictionaries Online Blog, Buzzword Archive by K. Maxwell in Macmillan Dictionary, Oxford Advanced Learner's Dictionary Tenth Edition by A. Lea and J. Bradbery, Urban Dictionary, Word Spy. The research data also include new vocabulary from relevant Internet sites, such as www.nytimes.com;

http://www.theguardian.com; http://nypost.com; http://www.dailymail.co.uk etc.

The choice of methods for the current research is based on its aim, objectives and the collected data.

Therefore, the following linguistic methods have been used: 1) structural (to study the derivational potential of the neologisms coined in online communication as well as to examine blending, compounding and affixation as productive neological techniques in the modern English language); 2) semantic (to analyse the lexical meanings of online vocabulary under investigation); 3) classification and systematisation (to group neologisms into particular categories on the basis of their meanings).

\section{Results and Discussion}

Nowadays the World Wide Web serves as a fruitful corpus of recently-produced texts which contain newly coined words (Cook, 2010). In the framework of this research we study numerous neologisms naming various types of selfies. Owing to the fact that the number of the latter is permanently growing, -fie is recognised as a suffix by certain linguists (Peters, 2014) and we also share this opinion.

A recent coinage Generation me (compounding) (Cambridge Dictionary, 2021). denotes the people born at the beginning of the $21^{\text {st }}$ century most of whom are more self-centered than previous generations. On the other hand, digitization of communication has created generation scroll (compounding) (Cambridge Dictionary, 2021), i.e. the people who communicate, read news, watch TV etc on their computers or telephones rather than socialize face-to-face. There is even a neologism triplescreen (compounding) (Lea \& Bradbery, 2020), which describes the actions of those who simultaneously use their phones, laptops and televisions.

Let us consider the 'selfie' neologisms that name certain body parts. Should a person believe her/his legs, feet or toes deserve public attention, they may want to share them with their online friends and followers by posting legsies (affixation legs+ies), footsies (affixation foot + s+ies), (Cambridge Dictionary, 2021). footfies (affixation foot+fies) (Peters, 2014), selfeets (blending self + feet $+s$ ) (Word Spy, 2022), and toefies (affixation toe+fies) (Peters, 2014). The limbs may as well be photographed on the background of some beautiful places proving that the legs'/feet's owner is enjoying him/herself and wants to share their happiness with less lucky online users. Shoefies (affixation shoe+fies) (Cambridge Dictionary, 2021)., i.e. selfies of one's footwear are also becoming popular in social media.

A person's hair is one of the objects onliners brag about through helfies (affixation hair+fies), stunning manicure is shared through nailfies (affixation nail+fies). Mischievous tonguefies (affixation tongue+fies), boobfies (affixation boob+fies), and eyefies (affixation eye+fies) picture the photographers' tongues, boobs, and eyes correspondingly (Peters, 2014). Love for one's bottom encourages its owner to take belfies (blending bottom+selfies), bumfies (affixation bum+fies) or buttfies (affixation butt+fies) (Peters, 2014). Pictures of a person's naked or topless body are termed nudies (affixation nude+ies) (Hofmann, 2014). The latter have given rise to a sort of an online sexual revolution neologised as sexting (blending sex+texting) (Hofmann, 2014). However, sharers of nudies must bear in mind that there is always a chance that such pictures might be thoroughly studied by parent creepers (compounding) (Hofmann, 2014), i.e. parents who follow their children's social activity online. Creepers, stalkers or lurkers (affixation all the three creep+ers, stalk+ers, lurk+ers) (Hofmann, 2014) are the people who frequently visit a user's online profile, comment on their updates and/or might be inolved in trolling (Hofmann, 2014). 


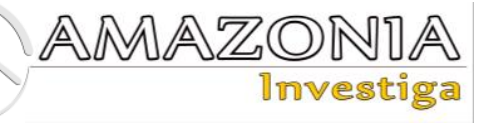

The people who pride themselves on being physically fit and yearn to demonstrate it to their friends and followers in social networks post welfies (blending workout+selfies), gelfies (blending gym+selfies) (Maxwell, 2003-2020), gymfies (affixation gym+fies) (Peters, 2014) and yogis (repurposing) (Maxwell, 2003-2020). It is worth mentioning that sometimes it is extremely difficult to guess the meaning of a certain neologism, especially without a supporting context. For instance, the abovementioned belfies and welfies in which only the first letter of the defining lexeme remains may baffle a listener.

A selfie portraying a drunk person is called a drelfie (blending drunk+selfie) (Maxwell, 20032020), and the one in which the drink (beer) is specified is a beerfie (affixation beer+fie) (Peters, 2014). Depending on the photographer's location, there are also bedfies (affixation bed+fies) and snowfies (affixation snow+fies), and for those less lucky - workfies (affixation work+fies) (Peters, 2014). On the other hand, more intelligent users promote reading habits by posting the pictures of themselves near their favourite bookshelves. Such shots are known as shelfies (affixation shelf+ies) (Maxwell, 20032020) or bookshelfies (affixation bookshelf+ies) (Maxwell, 2003-2020).

However, selfies are starting to face competition and there is a suggestion that the buzzwords couplie (affixation couple+ie) (Cambridge Dictionary, 2021), ussie (a 'selfie' of several friends) (affixation $u s+s+i e$ ) and grelfie (group selfie) (blending group+selfie) (Peters, 2014) might make selfies and their variations the thing of the past (Griffiths, 2014). The difference between the two types of photographs lies in the fact that couplies, grelfies and ussies are considered to be less egocentric than selfies, as they focus on relationships rather or more than on a person's physical valuables. Other possible options of group-taken selfies are threefies (affixation three+fies), fourfies (affixation four+fies), fivefies (affixation five + fies), and sixfies (affixation six + fies) (Peters, 2014).

The launch of a new smartphone, the Nokia 8, informally called The Bothie Phone, has revolutionized the way people take pictures due to the introduction of a dual sight-mode feature. The latter enables users to make hybrid photographs named bothies (affixation both+ies), i.e. split-screen photographs and videos shot with the help of front and back cameras simultaneously (Cambridge Dictionary, 2021). Undoubtedly, the bothie-bilities (affixation both+ie + blending bothie +abilities) of the model give the Nokia 8 an indisputable advantage over its market competitors in the Snapchat and Instagram era (compounding for both neologisms) (Pierce, 2017).

Technological advances and the introduction of drones to the mass-market have made dronies (affixation drone+ies) a new form of selfexpression that is on its way to make selfies outdated (Word Spy, 2022). Not only do drones allow people to take photographs, but short videos as well.

The neologism geobragging (affixation geo+bragging, although someone might treat it as a blend of geographic+bragging) names incessant 'updating of one's social network status with the information about one's current location aimed to show off and thus attract the attention of other users or make them jealous (Urban Dictionary, 2005-2020). A synonymous neologism is gloatgram (blending to gloat+Instagram), which may be either an Instagram post of one's geographic location or a picture of appetizing food (Urban Dictionary, 2005-2020).

One more trend in photographs posted on social media sites, plandids, portray a person who looks unaware that their picture is being taken. The blend of 'planned' and 'candid' seems to represent a huge fraud as the two lexemes contradict each other and staged photographs are in no way totally genuine and sincere (Lea \& Bradbery, 2020).

The so-called photoneologism felfie (blending farm + selfie) denotes a picture taken at a farm, i.e. with farming equipment or livestock (Gray, 2014). The trend has turned out so popular that it induced the creation of a website http://www.felfies.com/ on which farmers can share their photographs. Some online users are deeply convinced that their pets shouldn't be left aside online attention, which is why they might also share dogfies (affixation dog+fies) and catfies (affixation cat+fies) (Peters, 2014). Interestingly, dog shaming (compounding) is very popular with dog owners nowadays. When pet owners notice that their animal companions misbehave they may expose them to public criticism: a naughty pet is granted a 'guilty' sign around their neck and the picture is posted online (Cambridge Dictionary, 2021). As a matter of fact, the Facebook Dog shaming community has approximately 195, 000 subscribers. The online community of dog lovers is so large that there is a demand for dogfluencers (blending 
dog+influencers), i.e. dogs whose presence and photographs in social networks can promote a certain company or a brand (Cambridge Dictionary, 2021). It is, therefore, by no means surprising that DoggoLingo (affixation $($ doggy $>$ doggo $)+$ compounding doggo + lingo $)$ was developed (Cambridge Dictionary, 2021). The latter represents a special online language used mainly on social media sites to refer to canines and describe their behaviour.

It is worth mentioning that not all people demonstrate confidence when taking pictures of themselves for their social media accounts, some of them may feel selfie-conscious (compounding) (Urban Dictionary, 2005-2020) in public places as other people might be staring at them Bennett, 2014).

Moreover, there is a counterreaction on the part of those who disapprove of obsession with selfies, which is reflected in the neologisms depicting a pejorative attitude towards self-made portraits. One of the new coinages is narcisstick (blending narcissistic+selfie stick) (Word Spy, 2022), which some people frown upon by claiming that it takes the fun out of selfies by making the procedure too easy. On the other hand, monopod lovers argue that they allow one to take a prettier picture of oneself as one is not limited by the length of their arm (Goldberg, 2014).

The neologism ugly selfie (compounding) embodies one more backfire to narcissistic selfportraits. By posting unattractive selfies young people try to fight back the pressure modern standards of beauty and striving for physical perfection (at least in photographs) are exercising on them (Word Spy, 2022).

Moreover, obsession with selfies may have dramatic consequences for those wishing to stand out from the crowd and picture themselves in a particularly dangerous location. The neologism selfiecide and the derived adjective selfiecidal denote or characterize an accidental death which was caused by an attempt to take a selfie in a dangerous setting (Urban Dictionary, 20052020). For instance, a report in the Journal of Family Medicine and Primary Care in India indicates that 259 people died while taking selfies in dangerous places between 2011 and 2017 in comparison with only 50 people killed by sharks. The statistics sound alarming as in 2011, there were only three selfie-related deaths, however, in 2017 their number stood at 100 (Keeley, 2019). Some linguists treat selfiecide and selficidal as blends of 'selfie' and 'suicide' or 'suicidal' correspondingly, however, we believe -cide and -cidal are independent suffixes, therefore, in our opinion, the neologisms underwent affixation.

The Internet and social networks have become a treasure trove for global brands which advertise their products among users. Therefore, social networks are used by people not only for selfrepresentation and communication proper, for some individuals they are a source of income. There is a new category of online users called influencers (repurposing) (Urban Dictionary, 2005-2020) followed by a lot of people mostly on Instagram. Instafamous (blending Instagram+famous) (Urban Dictionary, 20052020) influencers usually include makeup, fashion, hairstyle or food bloggers who are sponsored by different companies to promote their products for a certain fee (sponcon (blending sponsored+content) and thus influence what people buy or the lifestyle they follow. A small number of followers on social media makes one a micro-influencer (affixation) (Cambridge Dictionary, 2021). On the other hand, outfluencers (blending out+influencers) propagate a more active lifestyle involving outdoor activities, extreme sports etc (Cambridge Dictionary, 2021).

There is one more cohort of Instagram influencers called cleanstagrammers (blending cleaning+Instagrammers) who post tips about cleaning and housework and promote certain cleaning products at the same time. Friendvertising (blending friend+advertising) is a means of promoting one's product when companies create heart-warming, touchy or funny videos that users will share with their social friends, however, all of them are still covert online commercials (Cambridge Dictionary, 2021).

Speaking about one of the most popular social networks all over the world nowadays Instagram, it is worth mentioning that sometimes users can have two accounts there: a rinsta (blending real+Instagram) (Urban Dictionary, 2005-2020) and a finsta (blending fake+Instagram) (Urban Dictionary, 2005-2020). The former is a socalled official, public one with no confidential information about the user, whereas the latter is followed by one's closest people only. Private and funny information and pictures are to be found in finsta, thus, the user won't be frowned upon by fellow students, colleagues and society in general (Urban Dictionary, 2005-2020). 


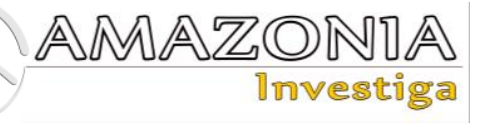

The results of spending too much time online and overusing one's gadgets can be both physical and psychological. Among the former, informal collocations tech neck (compounding) (Cambridge Dictionary, 2021). and text neck (compounding) (Maxwell, 2003-2020) characterize wrinkles on a person's neck and throat caused by lowering one's head to regularly use a phone, a laptop, a tablet computer etc.

Another example of a 'neck' neologism is an Internet frenzy called NekNomination (compounding neck+nomination) (Cambridge Dictionary, 2021). which is connected with alcohol abuse. To stay 'trendy', a user is supposed to post online a video of him/herself drinking (necking) a large portion of alcohol and the second rule stipulates that the act is to be recorded in some dangerous setting. At the end of the video the drinking hero (heroine) NekNominates (Cambridge Dictionary, 2021). (compounding neck+nominate) a person to continue the procedure and post their video online. Thus, the flashmob might involve a considerable quantity of people.

Interestingly, the metaphors in which a human body serves as a source domain according to G. Lakoff's theory are gaining ground in the sphere of modern technologies as well. One of the most recent language coinages exemplifying body-centrism is infobesity (blending information+obesity). Its synonyms such as over-consumption of information (compounding), the digital deluge (compounding) support the idea that humans confront and digest much more information than our ancestors (Coplin, 2014).

Addiction to social networks and crafting of one's online image may also cause hyperdocumentation (affixation) (Word Spy, 2022), which presents excessive description of one's daily activities in social media. The users who get carried away with sharing private information in social networks are now called datasexuals by analogy with metrosexuals (Word Spy, 2022). It is worth pointing out that -sexual along with-fie has also become one of the most productive suffixes in neology, giving rise to technosexuals, ecosexuals, sapiosexuals, fauxmosexuals, retrosexuals, ubersexuals (Word Spy, 2022) to name a few.

\section{Conclusions}

Nowadays digitization of communication has made people's self-representation online as and sometimes even more important than their offline appearance. The image a person creates in social networks is conveyed by a variety of means, and photographs, in particular, selfies have undoubtedly become one of the most widelyused tools to make one's profile attractive. The research has shown that selfies have given rise to a huge variety of 'spin-offs' which have been discussed in this work.

Different approaches to defining neologisms and nonce-formations have been analysed and our own definitions of the two phenomena have been provided in the framework of this research. We define neologisms as recently coined or existing words or word combinations which name new phenomena or concepts but which are still not actively used by most members of a speech community. By contrast, nonce-formations are either spontaneous coinages created to meet a one-off communicative need or intentional author's playful creations coined to impress a reader.

The practical focus of our research was on new types of selfies that are shared in social networks and other connected phenomena. The research has shown that different types of selfies make up the majority of analysed neologisms coined in the sphere of online communication $(51 \%$ of the analysed neologisms). Such an abundance of new types of selfies proves that self-centrism and obsession with one's body are firmly established in users' presence online, mostly in celebrities', adolescents' and young adults' social network profiles. The research has revealed that affixation is the most popular word-forming mechanism of new types of selfies and the notions connected with digital networking (50\% of the analysed neologisms). Neologisms coined by means of blending account for $26 \%$ of the total, compounding - for $19 \%$, repurposing and the combination of two word-forming mechanisms account for approximately $0,03 \%$ both. Therefore, the statistics gained in our research contradict with A. Bodle's (2016) aforementioned statement about portmanteau being the 'only player in town' in terms of neological formation. In our case it is affixation that wins first prize in word-forming competition.

Our future research will be devoted to other productive spheres in which modern neologisms are formed, in particular culture, ecology, economy, family, fashion, food, tourism etc. Moreover, other word-forming patterns, in particular, clipping, conversion, acronymy etc. will be analysed. 


\section{Bibliographic references}

Ahmad, K. (2000). Neologisms, Nonces and Word Formation, in: Heid, U., Evert, S., Lehmann, E., Rohrer, C. (eds.) Proceedings of the $9^{\text {th }}$ EURALEX Int. Congress, Vol. II. Munich, Germany: Universitat Stuttgart, pp. 711-730.

Ahmed, K. (2017). Are McJobs really history? BBC News. Recovered from: https://www.bbc.com/news/business40110399

Bennett, J. (2014). "With Some Selfies, the Uglier the Better". The New York Times. Recovered from: https://www.nytimes.com/2014/02/23/fashio $\mathrm{n}$ /selfies-the-uglier-the-bettertechnology.html?_r=1

Bodle, A. (2016). "How new words are born". The Guardian. Recovered from: https://www.theguardian.com/media/mindyour-language/2016/feb/04/englishneologisms-new-words

Cambridge Dictionary (2021). Cambridge words. About Words. Recovered from: https://dictionaryblog.cambridge.org

Capote Domínguez, T., González Hernández, G., \& Perdomo Ogando, J. (2019). El enfrentamiento al cambio climático en la especialidad forestal de la educación técnica profesional. Revista Científica Del Amazonas, 2(3), 5-16. Recuperado a partir de https://revistadelamazonas.info/index.php/a mazonas/article/view/13

Cook, C. P. (2010). Exploiting linguistic knowledge to infer properties of neologisms (PhD thesis) University of Toronto, Canada. Recovered from: https://tspace.library.utoronto.ca/bitstream/1 807/26140/9/Cook_C_Paul_201011_PhD_th esis.pdf

Coplin, D. (2014). Distracted By Work When on Holiday? You Might Be Suffering From Infobesity. HuffPost. Recovered from: https://www.huffingtonpost.co.uk/davecoplin/internetaddiction_b_5591831.html?guccounter=1

Crystal, D. (2008). A Dictionary of Linguistics and Phonetics. Oxford: England: WileyBlackwell.

Evans, R. L. (2012). Tyrannosaurus Lex: The Marvelous Book of Palindromes, Anagrams, and Other Delightful and Outrageous Wordplay. London, England: Penguin.

Fischer, R. (1998). Lexical change in present-day English: a corpus-based study of the motivation, institutionalization, and productivity of creative neologisms.
Tubingen, Germany: Gunter Narr Verlag Tubingen.

Goldberg, H. (2014). "Why the selfie stick is 2014's most controversial gift". New York Post. Recovered from: http://nypost.com/2014/12/17/why-theselfie-stick-is-the-most-controversial-gift-of2014

Gray, L. (2014). The felfie: how farmers are embracing social media. The Guardian. Recovered from: https://www.theguardian.com/environment/b $\log / 2014 /$ jan/12/felfie-farmers-social-media

Griffiths, S. (2014). It's official, group selfies are called an USIE - and they're taken to showcase relationships not vanity, claims expert. Daily Mail. Recovered from: http://www.dailymail.co.uk/sciencetech/artic le-2710871/Its-official-group-selfies-calledUSIE-theyre-taken-showcase-relationshipsnot-vanity-claims-expert.html

Hofmann, J. B. (2014). iRules: What Every Tech-Healthy Family Needs to Know about Selfies, Sexting, Gaming, and Growing up. USA: Rodale.

Hohenhaus, P. (2005). Lexicalization and institutionalization, in: P. Štekauer, R. Lieber (eds.), Handbook of Word-Formation: Studies in Natural Language and Linguistic Theory, 64. Berlin, Germany: Springer, pp. 353-373.

Horbach, O., \& Hryniuk, O. (2018). "Semantic aspect of compound neologisms in the modern German language (based in marketing lexis materials). Advanced Education, 5, 231-239. https://doi.org/10.20535/2410-8286.111193

Karpova, K. (2019). Structural and semantic characteristics of food-related neologisms in modern English. Advanced Education, 6(12), 206-211, https://doi.org/10.20535/24108286.144208

Keeley, M. (2019). More people die taking selfies than by shark attacks. Newsweek. Recovered from: https://www.newsweek.com/selfies-deadliershark-attacks-1446363

Lea, D., \& Bradbery, J. (2020). Oxford Advanced Learner's Dictionary Tenth Edition. Oxford, England: Oxford University Press.

Lehrer, A. (1996). Identifying and interpreting blends: An experimental approach. Cognitive Linguistics, 7(4), pp. 359-390.

Maxwell, K. (2006). "How are new words born?", Macmillan Dictionaries. Recovered from:

http://macmillandictionaries.com/MEDMagazine/April2006/37-New-Word.htm 
Maxwell, K. (2003-2020). Buzzwords by Macmillan Dictionary. Recovered from: https://www.macmillandictionary.com/buzz word/index.html

McMahon, A. S. (1994). Understanding Language Change. Cambridge and New York: Cambridge University Press.

Metcalf, A. A. (2002). Predicting New Words: The Secrets of Their Success. Boston, USA: Houghton Mifflin.

Minkova, D. \& Stockwell, R. (2009). English Words: History and Structure. Cambridge, England: Cambridge University Press.

Mostovyi, M. (1998). English movy lexicology [Leksykolohiia anhliiskoi movy]. Kharkiv, Ukraine: Osnova.

Nykytchenko, K. (2015). "To the problem of definition of 'occasionalism' among the basic notions of neology", Scientific Bulletin of Drohobych State Pedagogical University named after Ivan Franko. Ser.: Philological Sciences (Linguistics), 3, pp. 181-186.
Peters, M. (2014). "Selfie's Children: The Productive '-fie' Suffix". Visual Thesaurus. Recovered from: https://www.visualthesaurus.com/cm/diction ary/selfies-children-the-productive-fie-suffix

Pierce, D. (2017). "Nokia's New Phone Ushers in the Unfortunate Era of the "Bothie"'. Wired. Recovered from: https://www.wired.com/story/nokias-newphone-ushers-in-the-unfortunate-era-of-thebothie

Rey, A. (1995). Essays on Terminology. Amsterdam, the Netherlands: John Benjamins Publishing Company.

Stekauer, P. (2010). "On the Theory of Neologisms and Nonce-formations", Australian Journal of Liguistics, 97-112, doi.org/10.1080/07268600120122571

Urban Dictionary. (2005-2020). Web archive. Recovered from: https://www.urbandictionary.com

Word Spy. (2022). Web archive. Recovered from: https://www.wordspy.com 